\title{
Tectonic Origin Tsunami Scenario Database for the Marmara Region
}

\author{
Ceren Ozer Sozdinler ${ }^{1}$, Ocal Necmioglu ${ }^{2}$, H. Basak Bayraktar ${ }^{2,3}$, Nurcan M. Ozel ${ }^{2,4}$
}

${ }^{1}$ Institute of Education, Research and Regional Cooperation for Crisis Management Shikoku, Kagawa University, Takamatsu, 760-8521, Japan

$5 \quad{ }^{2}$ Department of Geophysics, Kandilli Observatory and Earthquake Research Institute, Bogazici University, Istanbul, 34684 , Turkey

${ }^{3}$ Department of Physics “Ettore Pancini”, University of Naples Federico II, Naples, 80126, Italy

${ }^{4}$ International Monitoring Systems, Comprehensive Nuclear-Test-Ban Treaty Organization, Vienna, 1400, Austria

Correspondence to: Ceren Ozer Sozdinler (cerenozr@cc.kagawa-u.ac.jp)

10 Abstract. This study presents the first tsunami scenario database in Marmara Sea, Turkey referring to 30 different earthquake scenarios obtained with the combinations of 32 possible fault segments. The fault mechanisms in Marmara Sea have been studied in detail within FP-7 MARSite project, which were derived from various databases and literature review. Tsunami simulations have been performed according to these defined 30 earthquake scenarios by tsunami numerical code NAMI DANCE (NAMIDANCE, 2011) which solves Nonlinear Shallow Water Equations (NLSWE) using leap-frog scheme. For

15 each earthquake scenario, tsunami hydrodynamic parameters, mainly maximum water surface elevations, arrival time of first wave and maximum wave, and water level fluctuations were calculated at 1333 synthetic gauge points meticulously selected along the coasts of Marmara Sea. The overall simulation results indicate that maximum expected wave heights due to these earthquake scenarios are between $1 \mathrm{~m}$ and $2 \mathrm{~m}$ and even more than $2 \mathrm{~m}$ at some locations along Marmara coasts, such as Kadikoy, Halic and Silivri coasts in Istanbul and Bayramdere and Kursunlu districts along the coasts of Bursa province. The

20 estimated maximum water levels at Bostanci, Pendik and Buyukada coasts in Istanbul, Cinarcik and Bandirma towns and at the entrance of Izmit Bay would reach up to $2 \mathrm{~m}$. Tekirdag coasts and Buyuk Cekmece and Bakirkoy coasts in Istanbul and Yalova coasts would experience maximum tsunami wave amplitudes around $1.5 \mathrm{~m}$. The waves reach up to $1 \mathrm{~m}$ at Izmit and Gemlik Bays, Erdek Peninsula and Marmara Island. The overwiew of the results reveal that higher historical tsunami wave heights observed in Marmara Sea cannot be explained by only earthquake-generated tsunamis. Therefore, there is strong

25 agreement on considering submarine landslides as the primary tsunami hazard component in the Marmara Sea as experienced during history and expected in the future.

\section{Introduction}

Marmara Region is located at the northwest part of Turkey, being one of the most important settlements throughout history as the passageway between two continents, Europe and Asia. The region literally acts as the heart of economy in the country 30 hosting mainly the megacity Istanbul with a population of higher than 15 million and huge capacity of trading, various industrial facilities, ports, airports as well as other densely populated cities. 
Marmara Sea located in the middle of this region is seismically very active area having various faults of different types with great possibility of triggering big earthquakes larger than 7.0 (Ambraseys, 2002). There are large number of references in literature proving the generation of historical tsunamis in the Marmara Sea caused by these earthquakes (Mihailovic 1927; Gundogdu 1986; Oztin and Bayülke 1991; Oztin 1994; Ambraseys and Finkel 1987, 1995; Altınok and Ersoy 2000; Arel and

5 Kiper 2000; Altınok et al. 2001, 2003, 2011; Yalciner et al. 2001a, b, c; Ambraseys 2002; Cetin et al. 2004; Rothaus et al. 2004; Tinti et al. 2006; Meral Ozel et al. 2011). The most significant ones among those are the Istanbul earthquakes on 10 September 1509, on 22 May 1766, and on 10 July 1894; the Sarkoy-Murefte earthquake on 9 August 1912; and the 17 August 1999 Kocaeli earthquake (Necmioğlu, 2016). During the 1509 earthquake, with a magnitude close to 8.0, the sea flooded the shores along Istanbul coasts, waves crashed against city walls and around 4000-5000 people died in the city (Ambraseys and

10 Finkel 1995). Tsunami waves with probably more than $6.0 \mathrm{~m}$ height overtopped the city walls and caused flooding (Oztin and Bayülke 1991). 1766 Istanbul earthquake, on the other hand, triggered tsunami with considerable in Gemlik Bay in Eastern Marmara (Ambraseys and Finkel 1995; Altınok et al. 2003).

There are mainly two motivations of this study: the first one is investigating the nature of historical tsunamis in Marmara Sea, namely whether they are generated solely due to those significant earthquakes or not. The second aim is directly correlated

15 with the operations of Regional Earthquake and Tsunami Monitoring Center (RETMC) in Kandilli Observatory and Earthquake Research Institute (KOERI) acting as 24/7 National Warning Center (NTWC-TR), which provides monitoring and warning services to the Eastern Mediterranean, Aegean, and Black Seas since 1 July 2012 under the framework of the Intergovernmental Coordination Group for the Tsunami Early Warning and Mitigation System in the North-eastern Atlantic, the Mediterranean and connected seas (ICG/NEAMTWS) initiative and has been accredited during 13th Session of ICG in

20 Bucharest, Romania, 26-28 September 2016 as a Tsunami Service Provider (TSP-TR). Due to short arrival times of first waves in Marmara coasts, having prepared tsunami scenarios covering various possible earthquakes is quite vital.

On account of this purpose and necessity, we have identified a comprehensive set of earthquake scenarios for the whole Marmara Region obtained by the compilation of historical records, past studies in literature and empirical results. These scenarios constitute the basis for tsunami numerical modeling conducted to obtain tsunami scenario database in Marmara Sea.

2532 different fault segments are finally determined in that manner of which methodology is described in the following section.

\section{Methodology}

\subsection{Identification of Earthquake Scenarios}

The main structural element controlling the morphological and structural features in Marmara Sea region is the northern strand of the North Anatolian Fault zone, which considered as a principal strike-slip displacement zone (Alpar and Yaltırak, 2002).

30 The North Anatolian Fault (NAF) is a major right-lateral, strike-slip fault that extends more than $1200 \mathrm{~km}$ from eastern Turkey to the north Aegean Sea (Sengör et al., 2005). It accommodates the relative right-lateral motion between the Anatolian region and Eurasia at a geodetic rate of $\sim 25 \mathrm{~mm} / \mathrm{yr}$ (Meade et al., 2002; Reilinger et al., 2006). Along its westernmost segment, the 
fault bifurcates into northern and southern branches, the northern branch following Izmit Bay and entering the Sea of Marmara southeast of Istanbul. By far the majority of long-term fault slip occurs on the northern fault branch following the northwest striking Princes' Islands Fault (PIF) and joining the east-west striking Central Marmara Fault (CMF) immediately south of Istanbul [Le Pichon et al., 2001; Armijo et al., 2005]. After traversing much of the Sea of Marmara, the CMF merges with the

5 Ganos Fault, exiting the Sea along the Ganos Peninsula. Ergintav et al. (2014) concluded that the Princes' Islands segment is most likely to generate the next M > 7 earthquake along the Sea of Marmara segment of the NAF. Armijo et al. (2005) stated that a zone of maximum loading with at least 4-5 m of slip deficit encompassing the strike-slip segment $70 \mathrm{~km}$ long between the Cinarcik and Central Basins would alone be capable of generating a large-magnitude earthquake in the order of Mw 7.2. Hergert et al. (2011) argues indicate that the Main Marmara Fault can be interpreted as a through-going fault that slips almost

10 purely in a strike-slip sense, but they also point out that, not contradictory to the previous statement, there is significant dipslip motion at some sections of the Main Marmara Fault. The South Marmara Fault lies between the highly active northern branch and the weakly active (but still capable of generating magnitude 7 earthquakes) southern branch (Pichon et al., 2014).

The geometry of the possible tsunamigenic faults in the Marmara Sea has been derived from the GIS Database of the fault 15 parameters in the Marmara region produced within MARsite - New Directions in Seismic Hazard assessment through Focused Earth Observation in the Marmara Supersite (FP7 Project-ENV.2012 6.4-2, Grant 308417). Fault parameters, on the other hand, were subjectively assigned through an extensive review of the literature (Alpar and Yaltırak, 2002; Altınok and Alpar, 2006; Armijo et al., 2005; Ergintav et al., 2014; Gasperini et al., 2011; Hebert et al., 2005; Hergert et al., 2011; Hergert and Heidbach, 2010; Imren et al.; 2001; Kaneko, 2009; Le Pichon et al., 2001; Le Pichon et al., 2003; Le Pichon et al. 2014;

20 Oglesby and Mai, 2012; Sengor et al.,2014; Tinti et al., 2006; Utkucu et al., 2009). Based on the databases and literature review, faults segments were simplified in order to be able to use them as input for tsunami modelling, where each segment correspond to a rectangular area with an associated hypothetical uniform slip (Figure 1). All parameters required for the identification of the segments, such as geographical coordinates for the start- and end-points of the segments, hypocentre, type of fault, strike, dip, rake, length and width of the segment, focal depth (where the top of the fault has been set to $0.5 \mathrm{~km}$ depth) and corresponding displacements according to empirical relations provided by Leonard (2010) and Wells and Coppersmith (1994) are presented in Table 1. This was followed by the definition of different hypothetical rupture scenarios reaching a total number of 30 scenarios as described in Table 2. In each scenario, special attention was given that the total earthquake moment derived from the summation of the earthquake moments, which are assigned to each segment, has been preserved by each scenario obtained through the combination of several segments. Slip values have been assigned using the same logic but in an

30 arbitrary manner without any prior assumption, so that heterogeneous earthquake rupture scenarios can be represented. Figure 2 shows the map of all earthquake scenarios collectively including the fault segments (green lines) assigned accordingly. 


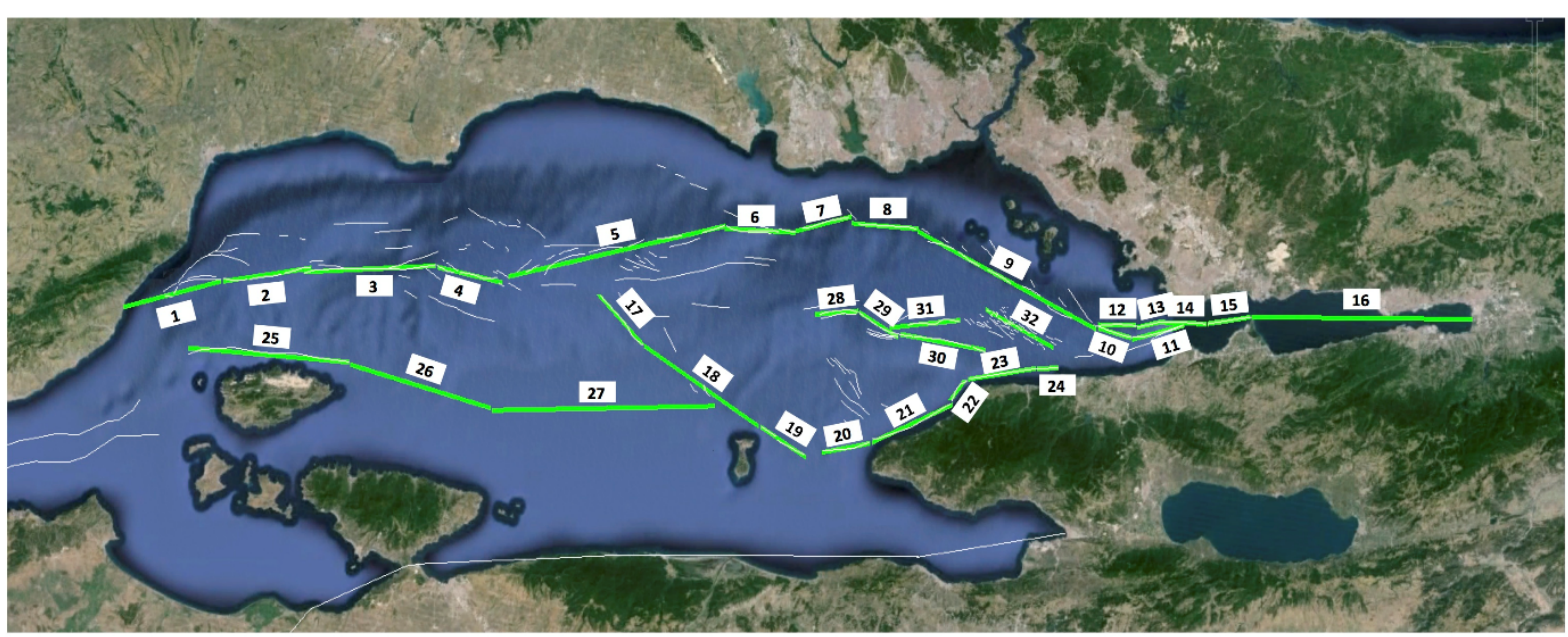

Figure 1: Simplified fault segments in Marmara identified for tsunami modelling. Segments correspond to a rectangular area with an associated uniform slip.

\section{$5 \quad 2.2$ Tsunami Numerical Modeling}

Based on 30 earthquake scenarios defined in Section 2.1, tsunami numerical modeling has been performed using the numerical code NAMI DANCE (NAMIDANCE, 2011), which solves Nonlinear Shallow Water Equations (NLSWE) with leap-frog scheme both in Cartesian and Spherical coordinate system. NAMIDANCE was tested, validated and verified against analytical solutions, laboratory measurements and field observations in several scientific articles (NTHMP, 2017; Lynett et al., 2017;

10 Velioğlu, 2017).

Tsunami numerical modelling is performed using $90 \mathrm{~m}$ grid sized bathymetry - topography data as a single study domain, which includes multi-beam bathymetric measurements and 900m grid sized GEBCO data in the sea and 30m grid sized ASTER data on land. Besides, coastline and coastal defence structures i.e. breakwaters, groins and large docks in the ports were also digitized in GIS environment and added to bathymetry - topography data for increasing the resolution and precision in coastal zones.

The initial sea surface at the time of fault rupture for each segment has been calculated using Okada (1985) formula. In each scenario, it was assumed that all designated fault segments are ruptured at the same instance. NAMIDANCE calculates the sea surface after the rupture of each segment and combines them in order to output the final sea surface that was used as the tsunami source of each scenario. For instance for Earthquake Scenario \#1 (SN01), segment-1, segment-2, segment-3 and segment-4 are the fault components designated for this scenario. The sea surface for each fault segment was calculated using Okada (1985) formula as if they are rupturing at the same instance. NAMIDANCE then outputs a final sea surface as the combination of these four segments as an overall tsunami source for SN01. We applied same procedure for all earthquake scenarios accordingly. 
The synthetic gauge points along the coasts of Marmara Sea were selected with very sensitive analysis so as to locate them in shallow zone at water depths less than $20 \mathrm{~m}$. We considered the locations of industrial facilities, residential areas, harbors, marinas, factories and six Tsunami Forecast Points (TFPs) while selecting those gauge points (TFPs are located at Marmara Eregli, Haydarpasa, Yalova, Mudanya, Erdek and Degirmencik, where the arrival time of first wave and tsunami alert level

5 are calculated and included in national tsunami alert messages disseminated from Regional Tsunami and Earthquake Monitoring Center in KRDAE; see Figure 3). The total number of gauge points is 1333 located at the water depths of less than $5 \mathrm{~m}$. The northern part of the area has much more important locations then the southern part, therefore gauge points in the northern part is denser than the southern part.

The maximum and minimum water surface elevations of tsunami sources calculated for each scenario are given in Table 3. As

10 seen from the table, the initial sea surface disturbances for all scenarios are less than $1 \mathrm{~m}$. The highest sea surface was calculated for SN23, which includes the rupture of segments 17, 18 and 19 located at the center of Marmara Sea raking in NW-SE direction.

Tsunami simulations were conducted for each scenario during 2 hours using the corresponding tsunami sources. Tsunami hydrodynamic parameters such as maximum and minimum wave amplitudes, arrival times of first and maximum wave, flow

15 depths and current velocities were calculated throughout Marmara basin and at 1333 synthetic gauge points. We discuss the simulation results in the following section in an integrated manner instead of giving the details of each scenario results in the main text of this paper. However, the distributions of maximum wave amplitudes and arrival time of first wave plotted for each scenario are provided in Supplementary Material. These plots directly reflect the hydrodynamic parameters calculated at each synthetic gauge point according to the defined color scale. The maximum wave amplitudes less than $25 \mathrm{~cm}$ (accepted as

20 threshold for critical water level that has potential to fall a person down) were colored with green as a representative of relatively safer coastal zones of Marmara Sea. Besides, Supplementary Material also includes water level fluctuations calculated for each scenario at six TFPs (Haydarpasa, Yalova, Mudanya, Erdek, Degirmencik and M. Eregli) and also 20 other locations that are selected out of 1333 synthetic gauge points considering the locations of industrial facilities, harbors, marinas, refineries and shipyards. These fluctuation plots also indicate the arrival time of first wave at each location. 
https://doi.org/10.5194/nhess-2019-186

Preprint. Discussion started: 8 July 2019

(c) Author(s) 2019. CC BY 4.0 License.
Natural Hazards and Earth System Sciences

Discussions

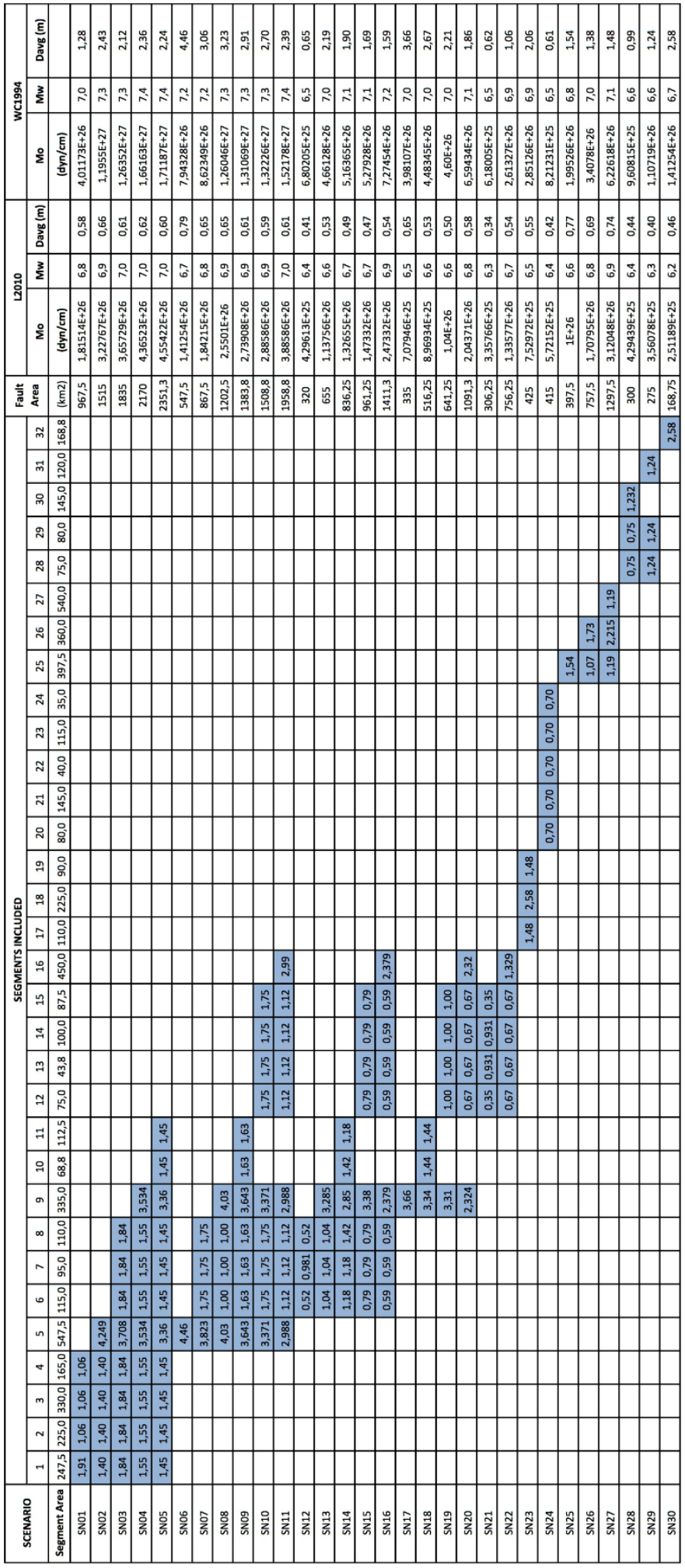


https://doi.org/10.5194/nhess-2019-186

Preprint. Discussion started: 8 July 2019

(c) Author(s) 2019. CC BY 4.0 License.

\section{Natural Hazards and Earth System Sciences \\ Discussions}
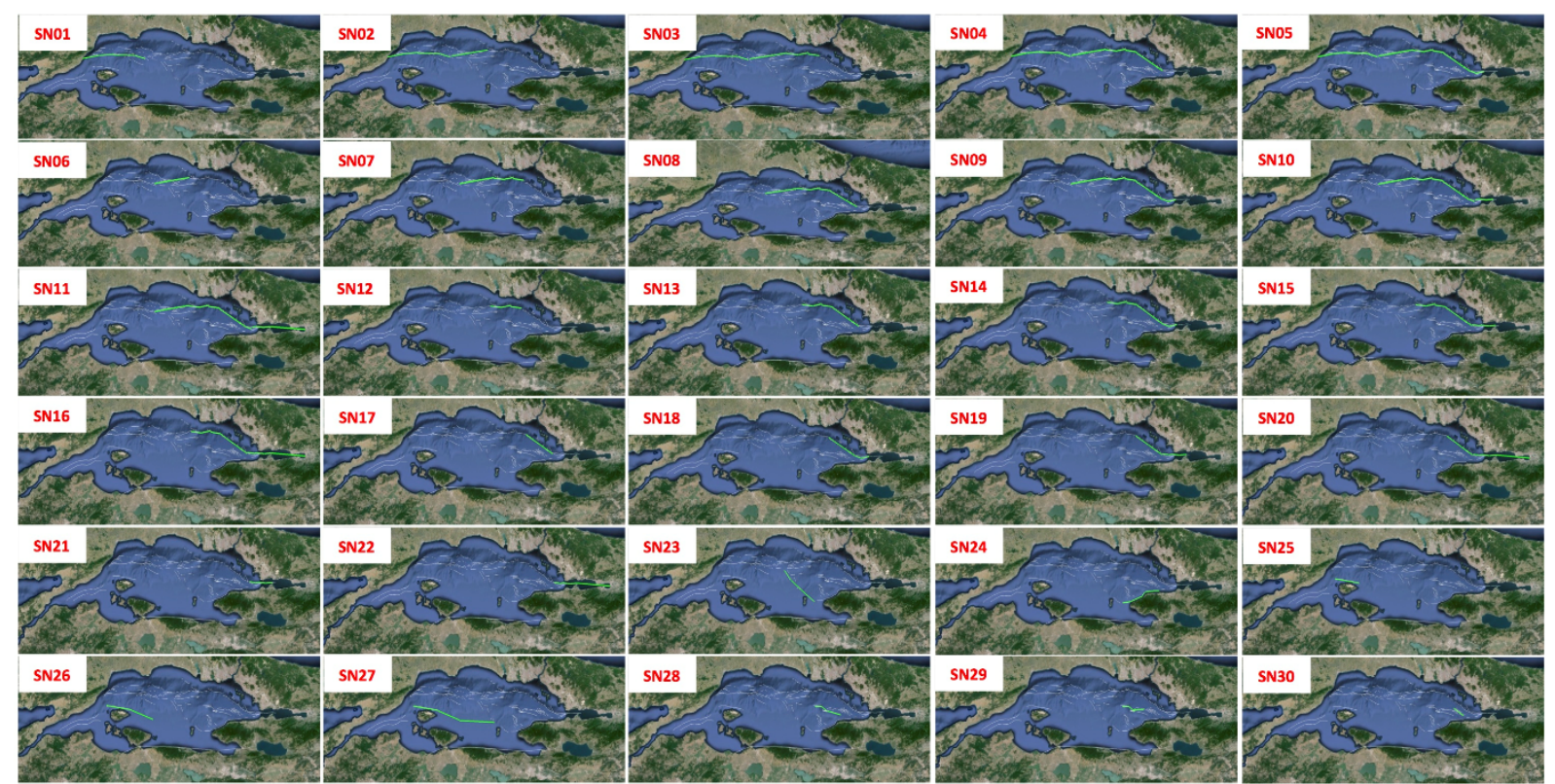

Figure 2: Map representation of the scenarios considered in this study.

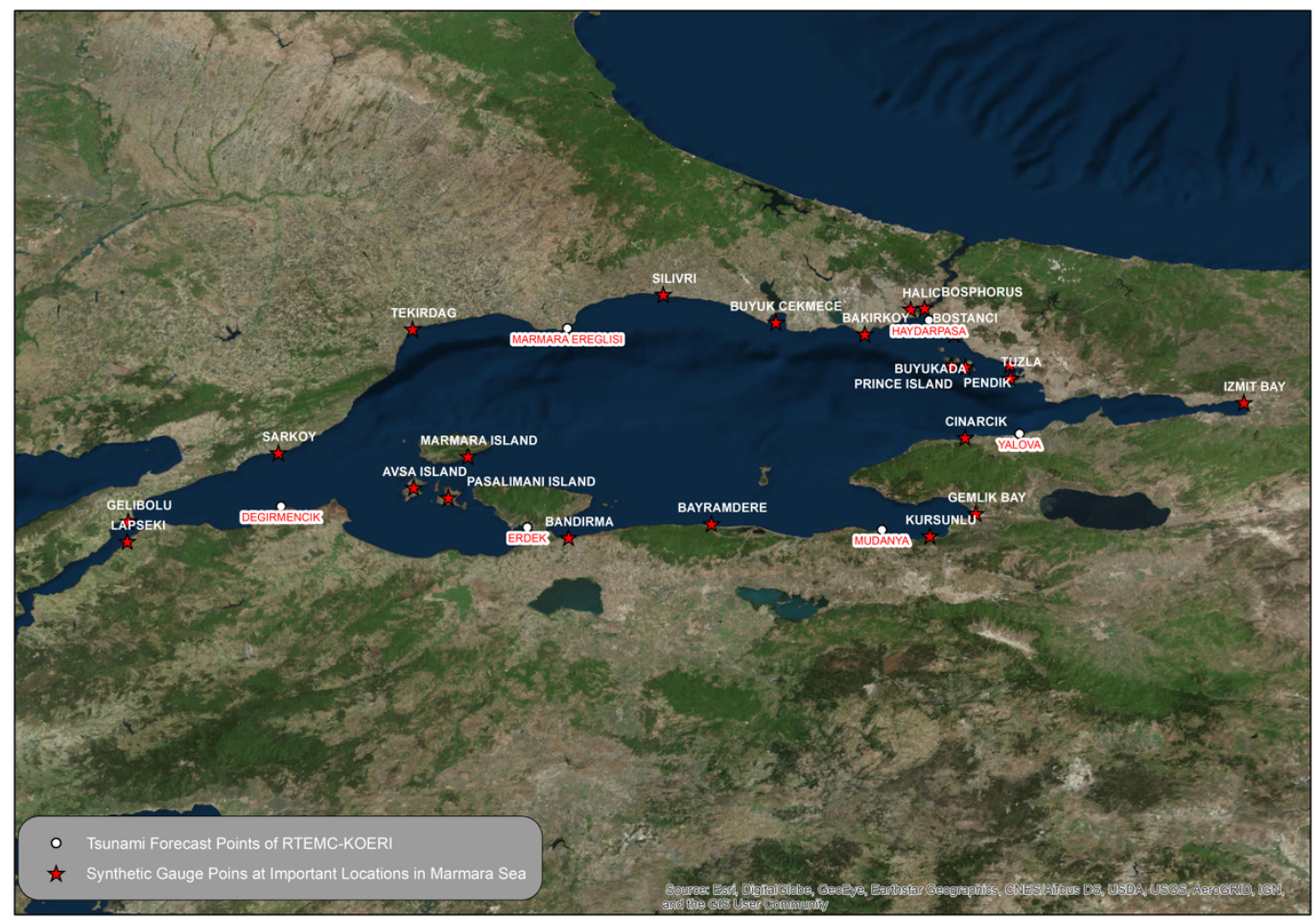

5 Figure 3: The locations of Tsunami Forecast Points (white dots and white-highlighted names written in red) and other important coastal districts (red stars and white names) where estimated tsunami effect is significant. 


\begin{tabular}{|c|c|c|c|}
\hline $\begin{array}{l}\text { NAME OF } \\
\text { SCENARIO }\end{array}$ & $\begin{array}{c}\text { MIN. WATER } \\
\text { SURFACE } \\
\text { ELEVATION (m) }\end{array}$ & $\begin{array}{l}\text { MAX. WATER } \\
\text { SURFACE } \\
\text { ELEVATION (m) }\end{array}$ & SEGMENTS \\
\hline SN01 & -0.08 & 0.07 & $1-2-3-4$ \\
\hline SN02 & -0.54 & 0.33 & $1-2-3-4-5$ \\
\hline SN03 & -0.47 & 0.29 & $1-2-3-4-5-6-7-8$ \\
\hline SN04 & -0.45 & 0.28 & $1-2-3-4-5-6-7-8-9$ \\
\hline SN05 & -0.43 & 0.26 & $\begin{array}{c}1-2-3-4-5-6-7-8-9- \\
10-11\end{array}$ \\
\hline SN06 & -0.58 & 0.33 & 5 \\
\hline SN07 & -0.50 & 0.29 & $5-6-7-8$ \\
\hline SN08 & -0.53 & 0.31 & $5-6-7-8-9$ \\
\hline SN09 & -0.48 & 0.28 & $5-6-7-8-9-10-11$ \\
\hline SN10 & -0.44 & 0.26 & $\begin{array}{c}5-6-7-8-9-12-13-14- \\
15\end{array}$ \\
\hline SN11 & -0.39 & 0.23 & $\begin{array}{c}5-6-7-8-9-12-13-14- \\
15-16\end{array}$ \\
\hline SN12 & -0.03 & 0.05 & $6-7-8$ \\
\hline SN13 & -0.39 & 0.25 & $6-7-8-9$ \\
\hline SN14 & -0.33 & 0.22 & $6-7-8-9-10-11$ \\
\hline SN15 & -0.41 & 0.26 & $6-7-8-9-12-13-14-15$ \\
\hline SN16 & -0.29 & 0.18 & $\begin{array}{c}6-7-8-9-12-13-14- \\
15-16\end{array}$ \\
\hline SN17 & -0.48 & 0.28 & 9 \\
\hline SN18 & -0.44 & 0.25 & $9-10-11$ \\
\hline SN19 & -0.44 & 0.25 & $9-12-13-14-15$ \\
\hline SN20 & -0.31 & 0.18 & $9-12-13-14-15-16$ \\
\hline SN21 & -0.033 & 0.05 & $12-13-14-15$ \\
\hline SN22 & -0.04 & 0.06 & $12-13-14-15-16$ \\
\hline SN23 & -0.61 & 0.39 & $17-18-19$ \\
\hline SN24 & -0.03 & 0.04 & $20-21-22-23-24$ \\
\hline SN25 & -0.07 & 0.10 & 25 \\
\hline SN26 & -0.08 & 0.09 & $25-26$ \\
\hline SN27 & -0.06 & 0.10 & $25-26-27$ \\
\hline SN28 & -0.05 & 0.07 & $28-29-30$ \\
\hline SN29 & -0.09 & 0.23 & $28-29-31$ \\
\hline SN30 & -0.44 & 0.25 & 32 \\
\hline
\end{tabular}

Table 3: Maximum and minimum water surface elevations of tsunami sources calculated for each earthquake scenario with corresponding fault segments

\section{$5 \quad 2.3$ Summary of Results}

As described in previous section, the simulation results are presented here as an integrated distribution of maximum wave amplitudes for overall tsunami scenario database in Marmara Sea. The maximum wave amplitudes were calculated at each synthetic gauge point for 30 earthquake scenarios. The calculated results of all scenarios at each gauge point were sorted from 
https://doi.org/10.5194/nhess-2019-186

Preprint. Discussion started: 8 July 2019

(c) Author(s) 2019. CC BY 4.0 License.
Natural Hazards

and Earth System

Sciences

Discussions

larger to smaller and the highest value was stored as the representative maximum wave amplitude at this gauge point. After defining all maximum wave amplitude values at 1333 synthetic gauge points, their integrated distribution was plotted for entire Marmara Sea (Figure 4). As described in previous section, the coastal zones with green color represents relatively safer locations according to the earthquake scenarios used in this database.

5 Following the same procedure, the integrated distribution of arrival time of maximum waves (that is exactly the time of occurrence of maximum wave amplitude at each gauge point in entire earthquake scenarios) was plotted in Figure 5. The results show that the arrival of maximum waves is expected at Prince Islands, Yalova coasts, some parts of Kadikoy and Silivri coasts within 5 minutes as critically short time for evacuation (refer to Figure 3 for the locations of affected districts).

Due to the evaluation of the modeling results for all earthquake scenarios, maximum wave amplitudes would be estimated

10 between $1 \mathrm{~m}$ and $2 \mathrm{~m}$ and even more than $2 \mathrm{~m}$ at some locations along Marmara coasts. The results show that the maximum wave amplitudes for Kadikoy, Halic and Silivri coasts in Istanbul and Bayramdere and Kursunlu districts along the coasts of Bursa province would be more than $2 \mathrm{~m}$. The estimated maximum water levels at Bostanci, Pendik, Buyukada coasts in Istanbul; and Cinarcik, Bandirma and at the entrance of Izmit Bay would reach up to 2m. Tekirdag coasts especially M. Eregli, B. Cekmece and Bakirkoy coasts in Istanbul and Yalova coasts would experience maximum tsunami wave amplitudes around

$151.5 \mathrm{~m}$. The waves reach up to $1 \mathrm{~m}$ at Izmit and Gemlik Bays, Erdek Peninsula and Marmara Island. A summary of the simulation results for all earthquake scenarios are given in Table 4 including the calculated maximum wave amplitudes for corresponding earthquake scenario and the names of most affected coastal regions.

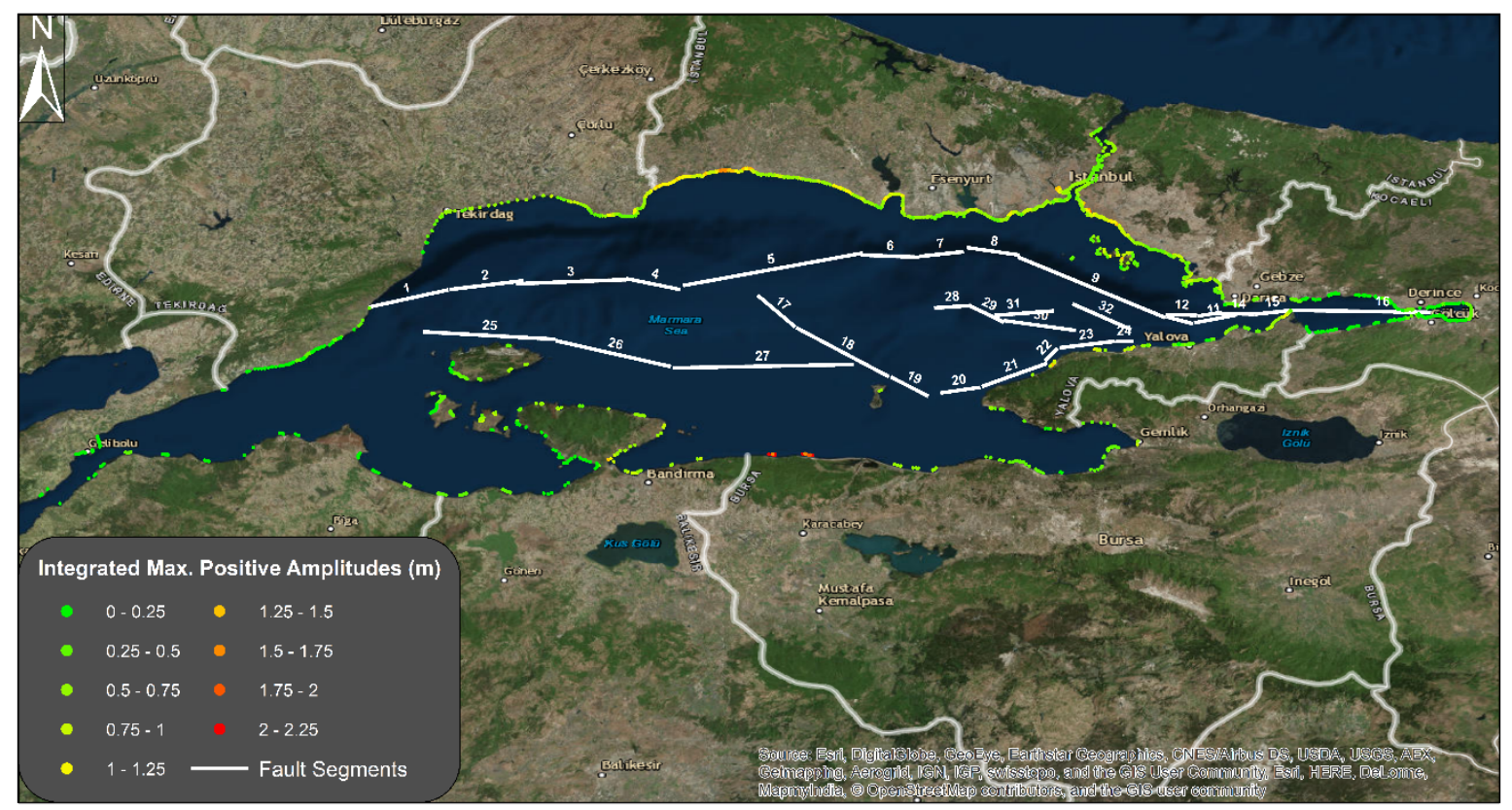

20 Figure 4: The integrated distribution of maximum wave amplitudes calculated at each gauge points for all earthquake scenarios 


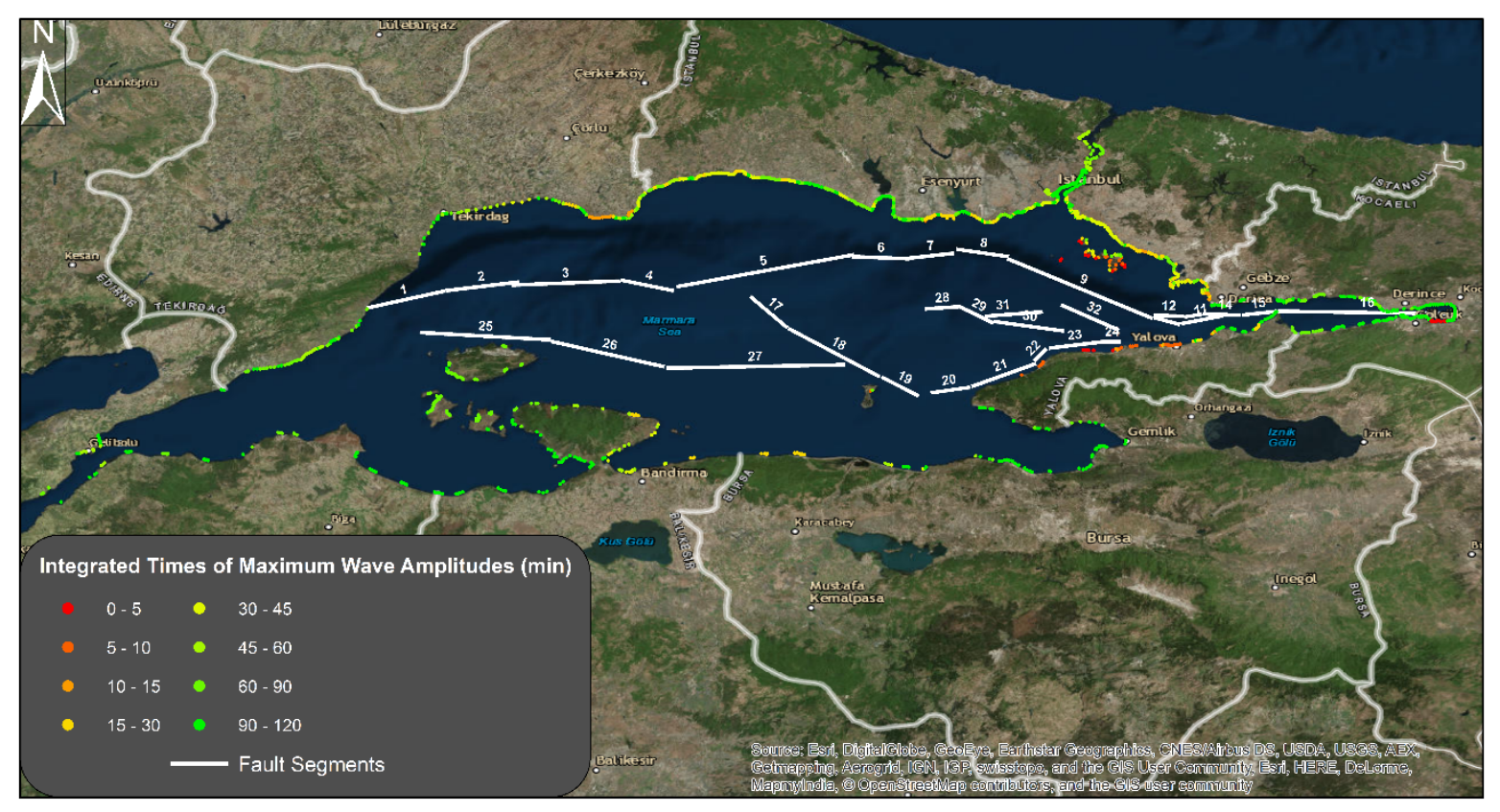

Figure 5: The integrated distribution of arrival times of maximum wave amplitudes calculated at each gauge points for all earthquake scenarios

\begin{tabular}{|c|c|c|}
\hline $\begin{array}{l}\text { Maximum wave } \\
\text { amplitude calculated }\end{array}$ & Corresponding scenario & Name of most affected coastal region \\
\hline $2 \mathrm{~m}-2.2 \mathrm{~m}$ & SN06 & $\begin{array}{l}\text { Kursunlu, Bayramdere, Eastern Silivri coasts, } \\
\text { Kadikoy, Halic }\end{array}$ \\
\hline $1.75 m-2 m$ & $\begin{array}{l}\text { SN02, SN03, SN07, } \\
\text { SN08, SN09, SN23 }\end{array}$ & $\begin{array}{l}\text { Bostanci, Pendik, Cinarcik, Bandirma and } \\
\text { Buyukada }\end{array}$ \\
\hline $1.5 m-1.75 m$ & SN04, SN05, SN10 & Western Silivri coasts, Kadikoy \\
\hline $1.25 m-1.5 m$ & $\begin{array}{l}\text { SN11, SN13, SN15, } \\
\text { SN17, SN18, SN19, } \\
\text { SN30 }\end{array}$ & $\begin{array}{l}\text { Prince Islands, Tekirdag, M. Eregli, Bakirkoy, } \\
\text { B. Cekmece, }\end{array}$ \\
\hline $1 \mathrm{~m}-1.25 \mathrm{~m}$ & SN14 & Yalova, Western Silivri coasts, Tuzla, Pendik \\
\hline $0.75 m-1 m$ & SN16, SN20, SN29 & $\begin{array}{l}\text { Izmit and Gemlik Bays, Erdek Peninsula, } \\
\text { Marmara Island }\end{array}$ \\
\hline Negligible effect & $\begin{array}{l}\text { SN01, SN12, SN21, } \\
\text { SN22, SN24, SN25, } \\
\text { SN26, SN27, SN28 }\end{array}$ & $\begin{array}{l}\text { Gelibolu, Lapseki, Degirmencik; Marmara, } \\
\text { Avsa and Pasalimani Islands; innermost } \\
\text { locations of Izmit and Gemlik Bays, northern } \\
\text { Bosphorus, west of Erdek Peninsula, Sarkoy } \\
\text { coasts }\end{array}$ \\
\hline
\end{tabular}

Table 4: The calculated maximum wave amplitudes with corresponding scenarios and the names of most affected coastal regions in Marmara Sea (the locations of affected coastal regions are shown on the map in Figure 3). 
As of doing deterministic tsunami hazard assessment, the maximum wave height calculated within entire tsunami scenario database in this study does not exceed $2.2 \mathrm{~m}$. However, we should note that this value would be naturally higher in terms of having probabilistic tsunami hazard assessment, i.e. as Hancilar (2016) provides inundation maps resulting from probabilistic tsunami hazard analysis for a $10 \%$ probability of exceedance in $50 \mathrm{yr}$ including the building numbers and types, lifeline systems

5 and demographic data in Istanbul. Hancilar (2016) also highlights that the residential buildings at risk are mainly located in Kadikoy, Tuzla, Bakirkoy and Prince Islands where our study points out significant wave heights as well.

\section{Conclusion}

This study, as the most comprehensive study so far to investigate the tsunami hazard due to earthquakes in the Marmara region, provides comprehensive tsunami scenario database including the estimated arrival times of first and maximum waves and

10 maximum wave heights along Marmara coasts as well as integrated coastal impact maps. The water level fluctuations at TFPs and critical important locations in the Marmara Sea are also presented for each earthquake scenario. The results show that higher historical tsunami wave heights observed in Marmara Sea cannot be explained by only earthquake generated tsunamis and submarine landslides should be considered as the primary tsunami hazard component in the Marmara Sea. Depending on the landslide volume fundamentally, as proved by several previous studies, possible tsunamis from submarine landslides in

15 the Marmara Sea could be significantly higher than those from earthquakes and waveforms from all the coasts around the Marmara Sea indicate that other residential areas might have had a high risk of tsunami hazards from submarine landslides, which can generate higher tsunami amplitudes and shorter arrival times, compared to Istanbul (Latcharote et al., 2016). To address this issue, Necmioglu (2016) proposed a tsunami warning system in the Marmara region coupled with the existing earthquake early warning system, which could work without waiting for any focal mechanism parameter determination that

20 may lead to underestimate tsunami hazards in the case of a strike-slip fault earthquake, due to the fact that submarine landslides could generate large tsunamis in the Marmara Sea. That coupling as well as the use of tsunami scenario database would enable RTEMC-KOERI to have most efficient operations in tsunami early warning in Marmara region without having any gaps in the system.

\section{Acknowledgements}

25 This work is supported by MARsite - New Directions in Seismic Hazard assessment through Focused Earth Observation in the Marmara Supersite (FP7 Project-ENV.2012 6.4-2, Grant 308417). We would like to thank Cengiz Zabc1 (Istanbul Technical University) and Pierre Henry, Julia Kende, Celine Grall (Centre Européen de Recherche et D'enseignement des Géosciences de L'environnement-CEREGE) for their study on "GIS database of the fault parameters" within MARSite. We would also like to acknowledge Earthquake and Tsunami Disaster Mitigation in the Marmara Region and Disaster Education 30 in Turkey (MARDiM) Project supported by Japan International Cooperation Agency (JICA). We also acknowledge Dr. Andrey 
Zaitsev, Prof. Dr. Ahmet Cevdet Yalciner and Bora Yalciner for their supports in using the tsunami numerical code NAMIDANCE.

\section{References}

Alpar, B. and Yaltırak, C.: Characteristic features of the North Anatolian Fault in the eastern Marmara region and its tectonic

5 evolution, Marine Geology 190, 329-350, 2002.

Altınok, Y., Alpar, B., Özer, N. and Aykurt, H.: Revision of the tsunami catalogue affecting Turkish coasts and surrounding regions, Natural Hazards Earth System Science, 11, 273-293, 2011.

Altınok, Y. and Alpar, B.: Marmara Island earthquakes, of 1265 and 1935; Turkey, Nat. Hazards Earth Syst. Sci., 6, 999-1006, 2006.

10 Altınok, Y., Alpar, B. and Yaltirak, C.: Sarkoy-Murefte 1912 Earthquake's Tsunami, extension of the associated faulting in the Marmara Sea, Turkey, J Seismol., 7, 329-346, 2003.

Altınok, Y. and Ersoy, S.: Tsunamis observed on and near the Turkish coasts, Natural Hazards, 21, 185-205, 2000.

Altınok, Y., Tinti, S., Alpar, B., Yalçıner, A. C., Ersoy, S., Bortolucci, E. and Armigliato, A.: The tsunami of August 17, 1999 in Izmit Bay, Turkey, Nat Hazards, 24, 133-146, 2001.

15 Ambraseys, N.: The seismic activity of the Marmara Sea region over the last 2000 years, Bulletin of the Seismological Society of America, 92, 1, 1-18, 2002.

Ambraseys N. N. and Finkel, C.: The seismicity of Turkey and adjacent areas. A historical review, 1500-1800, Eren Yayınc1lık, 1995.

Armijo, R., Pondard, N., Meyer, B., Uçarkus, G., Mercier de Lépinay, B., Malavieille, J., Dominguez, S., Gustcher, M-A.,

20 Schmidt, S., Beck, C., Çagatay, N., Çakir, Z., Imren, C., Eris, K., Natalin, B., Özalaybey, S., Tolun, L., Lefèvre, I., Seeber, L., Gasperini, L., Rangin, C., Emre, O., and Sarikavak, K.: Submarine fault scarps in the Sea of Marmara pull-apart (North Anatolian Fault): Implications for seismic hazard in Istanbul, Geochem. Geophys. Geosyst., 6, Q06009, doi:10.1029/2004GC000896, 2005.

Ergintav, S., Reilinger, R. E., Çakmak, R., Floyd, M., Çakır, Z., Dogan, U., King, R. W., McClusky, S., and Özener, H.:

25 Istanbul's earthquake hot spots: Geodetic constraints on strain accumulation along faults in the Marmara seismic gap, Geophys. Res. Lett., 41, doi:10.1002/2014GL060985, 2014.

Gundogdu, O.: Türkiye Depremlerinin Kaynak Parametreleri ve Aralarindaki Iliskiler (Source parameters of earthquakes in Turkey and their relationships), PhD Thesis, Istanbul University., p 120, 1986.

Hancilar, U.: Identification of elements at risk for a credible tsunami event for Istanbul, Natural Hazards \& Earth System

30 Sciences 12, 107-119, 2012.

Hebert, H., Schindele, F., Altinok, Y., Alpar, B., and Gazioglu, C.: Tsunami hazard in the Marmara Sea (Turkey): a numerical approach to discuss active faulting and impact on the Istanbul coastal areas, Marine Geology, 215, 23-43, 2005. 
Hergert, T. and Heidbach, O.: Slip-rate variability and distributed deformation in the Marmara Sea fault system, Nature Geoscience, 3, 2010.

Hergert, T., Heidbach, O., Becel, A., and Laigle, M.: Geomechanical model of the Marmara Sea region-I. 3-D contemporary kinematics, Geophys. J. Int., 185, 1073-1089, doi: 10.1111/j.1365-246X.2011.04991.x, 2011.

5 Imren, C., Le Pichon, X., Rangin, C., Demirbag, E., Ecevitoglu, B. and Gorur, N.: The North Anatolian Fault within the Sea of Marmara: a new interpretation based on multi-channel seismic and multi-beam bathymetry data, Earth and Planetary Science Letters 186, 143-158, 2001.

Latcharote, P. Suppasri, A., Imamura, F., Aytore, B., and Yalciner, A. C.: Possible worst-case tsunami scenarios around the Marmara Sea from combined earthquake and landslide sources, Pure and Applied Geophysics, 173 (2), 3823-3846, 2016.

10 Le Pichon, X., Imren, C., Rangin, C., Sengor, A. M. C., and Siyako, M.: The South Marmara Fault, Int J Earth Sci (Geol Rundsch), 103, 219-231, doi: 10.1007/s00531-013-0950-0, 2014.

Le Pichon, X., Chamot-Rooke, N., Rangin, C, and Sengor, A. M. C.: The North Anatolian fault in the Sea of Marmara, Journal of Geophysical Research, 108, B4, 2179, doi:10.1029/2002JB001862, 2003.

Le Pichon, X., Sengor, A. M. C., Demirbag, E., Rangin, C., Imren, C., Armijo, R., Gorur, N., Cagatay, N., Mercier de Lepinay,

15 B., Meyer, B., Saatcilar, R., and Tok, B.: The active Main Marmara Fault, Earth and Planetary Science Letters, 192, 595-616, 2001.

Kaneko, F.: A Simulation Analysis of Possible Tsunami affecting the Istanbul Coast, Turkey, International Workshop on Tsunami Hazard Assessment and Management in Bangladesh, 2009.

Leonard, M.: Earthquake Fault Scaling: Self-Consistent Relating of Rupture Length, Width, Average Displacement, and 20 Moment Release, Bulletin of the Seismological Society of America, 100, No. 5A, 1971-1988, doi: 10.1785/0120090189, 2010. Gasperini, L., Polonia, A., Bortoluzzi, G., Henry, P., Le Pichon, X., Tryon, M., Çagatay, N., and Géli, L.: How far did the surface rupture of the 1999 Izmit earthquake reach in Sea of Marmara, Tectonics, 30, TC1010, doi:10.1029/2010TC002726, 2011.

Lynett, P. J., Gately, K., Wilson, R., Montoya, L., Arcas, D., Aytore, B., and David, C. G.: Inter-model analysis of tsunami25 induced coastal currents, Ocean Modelling, 114, 14-32, 2017.

Meade, B. J., Hager, B. H., McClusky, S. C., Reilinger, R. E., Ergintav, S., Lenk, O., Barka, A., and Ozener, H.: Estimates of seismic potential in the Marmara region from block models of secular deformation constrained by GPS measurements, Bull. Seismol. Soc. Am., 92, 208-215, 2002.

Mihailovic, J.: Memoir-Sur les Grands Tremblement de Terre de la Mer de Marmara, Beograd, 215-222, 1927.

30 Utkucu, M., Kanbur, Z., Alptekin, O., and Sumbul, F.: Seismic behaviour of the North Anatolian Fault beneath the Sea of Marmara (NW Turkey): implications for earthquake recurrence times and future seismic hazard, Nat Hazards, 50, 45-71, doi:10.1007/s11069-008-9317-4, 2009.

NAMI DANCE: Manual of Numerical Code NAMI DANCE, published in http://namidance.ce.metu.edu.tr, 2011. 
Necmioglu, O.: Design and challenges for a tsunami early warning system in the Marmara Sea, Earth, Planets and Space, 68:13, doi: 10.1186/s40623-016-0388-2, 2016.

Necmioglu, O., and Ozel, N. M.: Earthquake Scenario-Based Tsunami Wave Heights in the Eastern Mediterranean and Connected Seas, Pure and Applied Geophysics, doi:10.1007/s00024-015-1069-y, 2015.

5 NTHMP: Proceedings and Results of the National Tsunami Hazard Mitigation Program 2015 Tsunami Current Modeling Workshop, 2015.

Oglesby, D. D. and Mai, P. M.: Fault geometry, rupture dynamics and ground motion from potential earthquakes on the North Anatolian Fault under the Sea of Marmara, Geophys. J. Int., 188, 1071-1087, doi: 10.1111/j.1365-246X.2011.05289.x, 2012. Okada, Y.: Surface Deformation Due to Shear and Tensile Faults in a Half-Space, Bull. Seis. Soc. Am., 75, 4, 1135-1154, 101985.

Oztin, F.: 10 Temmuz 1894 Istanbul Depremi Raporu, T.C. Bayindirlik ve Iskan Bakanligi, Afet Isleri Genel Mudurlugu, Deprem Arastırma Dairesi, (Report on 10 July 1894 Istanbul Earthquake by Ministry of Public Works and Settlement, General Directorate of Disaster Affairs, Department of Earthquake Research), Ankara, 1994.

Oztin, F. and Bayülke, N.: Historical earthquakes of Istanbul, Kayseri, Elazıg. In: Proceedings of the workshop on historical 15 seismicity and seismotectonics of the Mediterranean region, 10-12 October 1990 (Istanbul), Turkish Atomic Energy Authority, Ankara, pp 150-173, 1991.

Reilinger, R., et al.: GPS constraints on continental deformation in the Africa-Arabia-Eurasia continental collision zone and implications for the dynamics of plate interactions, J. Geophys. Res. 111, B05411, doi:10.1029/2005JB004051, 2006.

Şengör, A. M. C., Grall, C., Imren, C., Le Pichon, X., Görür, N., Henry, P., Karabulut, H., and Siyako, M.: The geometry of 20 the North Anatolian transform fault in the Sea of Marmara and its temporal evolution: implications for the development of intracontinental transform faults, Can. J. Earth Sci., 51, 222-242, dx.doi.org/10.1139/cjes-2013-0160, 2014

Şengör, A. M. C., Tuysuz, O., Imren, C., Sakınc, M., Eyidogan, H., Gorur, N., Le Pichon, X., and Rangin, C.: The North Anatolian fault: A new look, Annu. Rev. Earth Planet. Sci., 33, 37-112, 2005.

Tinti, S., Armigliato, A., Manucci, A., Pagnoni, G., Zaniboni, F., Yalciner, A. C., and Altinok, Y.: The generating mechanisms

25 of the August 17, 1999 Izmit bay (Turkey) tsunami: Regional (tectonic) and local (mass instabilities) causes, Marine Geology 225, 311-330, 2006.

Velioglu, D.: Advanced Two and Three Dimensional Tsunami Models: Benchmarking and Validation, Master's Thesis, Middle East Technical University, 2009.

Wells, D. L. and Coppersmith, K. J.: New empirical relationships among magnitude, rupture length, rupture width, rupture 30 area, and surface displacement, Bulletin of the Seismological Society of America, 84, 4, 974-1002, 1994. 